\title{
Aortic and iliac thrombosis in a dog with adrenal-dependent hypercortisolism due to bilateral adrenocortical adenoma
}

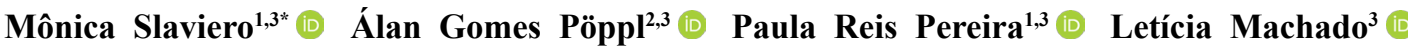 \\ Fabíola Peixoto da Silva Mello ${ }^{2}$ (1) Cristine Mari $^{4}$ (D) Welden Panziera ${ }^{1}$ (D) Saulo Petinatti Pavarini ${ }^{1,3}$ (i)
}

${ }^{1}$ Setor de Patologia Veterinária, Departamento de Patologia Clínica Veterinária, Faculdade de Veterinária (FAVET), Universidade Federal do Rio Grande do Sul (UFRGS), 91540-000, Porto Alegre, RS, Brasil. E-mail: monicaslav.vet@gmail.com.."Corresponding author. ${ }^{2}$ Departamento de Medicina Animal, Faculdade de Veterinária (FAVET), Universidade Federal do Rio Grande do Sul (UFRGS), Porto Alegre, RS, Brasil.

${ }^{3}$ Programa de Pós-graduação em Ciências Veterinárias, Faculdade de Veterinária (FAVET), Universidade Federal do Rio Grande do Sul (UFRGS), Porto Alegre, RS, Brasil

${ }^{4}$ Hospital de Clínicas Veterinárias, Faculdade de Veterinária (FAVET), Universidade Federal do Rio Grande do Sul (UFRGS), Porto Alegre, RS, Brasil.

ABSTRACT: Hypercortisolism is a common endocrinopathy in dogs; however, in a few cases, bilateral functional adrenocortical adenomas cause spontaneous disease, and thrombotic events are considered uncommon complications. The aim of this report was to describe a case of bilateral adrenocortical adenoma in a dog with hyperadrenocorticism associated with distal aortic and iliac thrombosis, with emphasis on clinical and pathological aspects. A 15-year-old spayed female Dachshund with a previous clinical history of hyperadrenocorticism presented with acute bilateral hindlimb paraparesis. A vertebral thoracolumbar radiography was performed and did not present any evidence of intervertebral disk disease or vertebral abnormalities; however, abdominal ultrasound and vascular Doppler evaluation revealed bilateral adrenal enlargement in addition to an aortic and external iliac artery thrombus. The animal was euthanized. At necropsy, both adrenal glands were enlarged by well-demarcated neoplastic nodules in the parenchyma, and a thrombus caudal to the abdominal aorta bifurcation within the external iliac arteries that extended to the left external iliac artery was noted. Histological evaluation revealed a well-differentiated neoplastic proliferation of cortical epithelial cells, consistent with bilateral adenoma, and muscular necrosis in the pelvic limbs was also observed. Bilateral functional adrenocortical adenoma; although, very rare, should be considered as a cause of hypercortisolism, and aortic thrombosis in dogs should be considered as a possible consequence.

Key-words: canine, aortic, thrombosis, hyperadrenocorticism, adrenal gland cortex.

Trombose aórtica e ilíaca em um cão com hipercortisolismo adrenal-dependente devido a adenoma adrenocortical bilateral

RESUMO: Hipercortisolismo é uma endocrinopatia comum em cães, no entanto, apenas em poucos casos adenomas adrenocorticais funcionais bilaterais são a causa de doença espontânea, e eventos trombóticos são considerados complicações incomuns. O objetivo deste relato foi descrever um caso de adenoma adrenocortical bilateral em um cão com hiperadrenocorticismo associado a trombose aórtica distal e ilíaca, com ênfase nos aspectos clínicos e patológicos. Um cão, Dachshund, fêmea castrada, de 15 anos, com histórico clínico prévio de hiperadrenocorticismo, apresentou paraparesia aguda dos membros posteriores. Foi realizada radiografia toracolombar vertebral, a qual não mostrou nenhuma evidência de doença do disco intervertebral ou anormalidades vertebrais; no entanto, ultrassonografia abdominal e Doppler vascular revelaram um trombo na aorta e artéria iliaca externa, e adrenomegalia bilateral. O animal foi submetido à eutanásia. Na necropsia, ambas as adrenais estavam distendidas por nódulos neoplásicos bem delimitados no parênquima e notou-se um trombo caudalmente à bifurcação da aorta abdominal às artérias ilíacas externas, estendendo-se à ilíaca externa esquerda. Na avaliação histológica observou-se proliferação neoplásica bem diferenciada de células epiteliais corticais, consistente com adenoma bilateral; também foi observada necrose muscular nos membros pélvicos. O adenoma adrenocortical funcional bilateral, embora muito raro, deve ser considerado uma causa de hipercortisolismo, e a trombose aórtica em cães deve ser considerada uma possível consequência.

Palavras-chave: caninos, aorta, trombose, hiperadrenocorticismo, córtex adrenal.

Canine hypercortisolism (HC), also known as Cushing's syndrome or hyperadrenocorticism (HAC), is a common endocrinopathy characterized by several clinical signs secondary to chronic exposure to glucocorticoid effects (SANDERS et al., 2018). Adrenocorticotropic hormone (ACTH)dependent form, which occurs as a result of corticotroph adenomas (pituitary-dependent $\mathrm{HC}$ ), is 
the most common cause of spontaneous disease in dogs (80-85\% of cases). Less commonly, ACTHindependent $\mathrm{HC}$ occurs as a result of a functional unilateral, or eventual bilateral, adrenal cortex neoplasia secreting cortisol autonomously (15-20\% of cases), and is also known as adrenal-dependent HC (ADH) (PETERSON, 2007; PACE et al., 2013). A variety of clinical manifestations can be observed for HC, of which thromboembolic events are considered to be uncommon complications. However, when thromboembolic events develop in dogs with Cushing's, pulmonary vessels are primarily involved (NICHOLS, 1997; BEHREND et al., 2013). The aim of this report was to describe the clinical and pathological aspects of distal aortic and iliac thrombosis in a dog with ACTH-independent $\mathrm{HC}$ associated with bilateral adrenocortical neoplasia.

A 15-year-old spayed, female Dachshund weighing $8.6 \mathrm{~kg}$ and exhibiting bilateral hindlimb paraparesis over the previous two days in addition to excessive vocalization was brought to a veterinary hospital. Eight months earlier, the dog was diagnosed with ADH based on the presence of classic clinical signs, compatible complementary exams, and a consistently positive low-dose dexamethasone suppression test (LDDST) (Table 1) (PETERSON, 2007; BEHREND et al., 2013). However, despite the diagnosis, the owners declined to initiate medical treatment with trilostane or mitotane.

On physical examination, severe bilateral alopecia and abdominal muscle atrophy associated with abdominal enlargement ("pot belly") were evident. The dog was normohydrated, capillary refill time was $<2$ seconds, and the dog also showed a good muscular mass index of 3/3, despite being overweight with a corporal condition score of 7/9 (ideal 5/9) (LAFLAMME, 1997). The left femoral pulse was absent or weak in the right side, and the temperature of the left hindlimb was clearly lower than that of the right hindlimb. A neurological exam showed no sign of brain impairment; however, the patient was very excited and vocalized during the exam. Although, nociception was still preserved in the hind limbs, the panniculus and patellar reflexes were bilaterally absent, and the flexor reflex was reduced in the left hindlimb. A blood sample collected for $\mathrm{CBC}$ and serum biochemistry analysis showed progression of the abnormalities previously reported upon the $\mathrm{ADH}$ diagnosis (Table 1). Mild thrombocytosis was also observed. A vertebral thoracolumbar radiography was performed and did not show any evidence of intervertebral disk disease or vertebral abnormalities; however, an abdominal ultrasound revealed bilateral adrenal enlargement progression (Table 1) in addition to an aortic and external iliac artery thrombus.

The aortic lumen was filled with echogenic material immediately caudal to external iliac arteries and measuring $1.8 \times 0.5 \mathrm{~cm}$. Moreover, hyperechogenic material measuring $2.25 \times 0.24 \mathrm{~cm}$ was also discovered inside the left external iliac artery. Vascular color Doppler evaluation showed a weak blood flow signal, with a $4.1 \mathrm{~cm} /$ second systolic peak velocity (SPV) (Reference value $145.79 \pm 25.28 \mathrm{~cm} / \mathrm{s}$ [MELLO et al., 2016]). A small reduction in blood flow was measured in the right femoral artery, with an $\mathrm{SPV}=70 \mathrm{~cm} / \mathrm{second}$, while a very weak blood flow was recorded in the left femoral artery, with an SPV $=5.8 \mathrm{~cm} /$ second. (Reference value $138.00 \pm 30.93$ [MELLO et al., 2016]). Due to the aortic thrombosis diagnosis, the owners decided upon euthanasia, and the dog was submitted for necropsy.

At necropsy, both adrenal glands were enlarged, and there were well-demarcated neoplastic nodules obliterating the parenchyma on the cut surface. The left adrenal gland was larger with a firm reddish mass at the caudal pole measuring approximately $3.0 \mathrm{~cm}$ in diameter. The right adrenal nodule was $1.4 \mathrm{~cm}$ in diameter, with a yellowish surface (Figure 1A). A $2.5 \mathrm{~cm}$ long thrombus was observed caudal to the abdominal aorta bifurcation within the external iliac arteries and extending the left external iliac artery (Figure 1B). No other thrombi were noted distally. No gross changes to the hypophysis were observed. Additionally, the skeletal musculature of both pelvic limbs had extensive pale whitish areas, and hepatomegaly was observed. Multiple tissue samples were collected, fixed in $10 \%$ neutral buffered formalin, routinely processed for histopathology, and stained with hematoxylin and eosin (HE).

Histological examination of the adrenal glands revealed a well-differentiated and partially encapsulated neoplastic proliferation of cortical epithelial cells, which replaced more than $80 \%$ of the parenchyma (Figure 1C). Tumor cells were polyhedral and arranged in nests, with a broad and finely vacuolated cytoplasm, oval nuclei, finely granular chromatin, and inconspicuous nucleoli (Figure 1D). Mitoses average less than one per individual 400x powered objective, and there was mild anisocytosis and anisokaryosis. Additionally, multifocal intratumoral necrosis, hemorrhage, mineralization, and thrombosis, as well as intratumoral extramedullary hematopoiesis, were identified. In addition, multiple, prominent dilated thin-walled sinusoids filled with blood were present (telangiectasis). The thrombus within the aortic and external iliac artery lumen was formed of 
Table 1 - Hematology, serum biochemistry, urine analysis, and an adrenal ultrasound of a patient at the time of hypercortisolism diagnosis and eight months later, at which time it was presented to the hospital with aortic thromboembolism.

\begin{tabular}{|c|c|c|c|}
\hline Parameter & Hypercortisolism Diagnosis & 8 mo later with thromboembolism & Reference Interval \\
\hline Erythrocytes $\left(\times 10^{6} / \mu \mathrm{L}\right)$ & 7.58 & 7.52 & $5.5 .-8.5$ \\
\hline Hemoglobin (g/dL) & 17 & 17.1 & $12-18$ \\
\hline Hematocrit (\%) & 47 & 49 & $37-55$ \\
\hline Platelets $\left(\times 10^{3} / \mu \mathrm{L}\right)$ & 500 & 520 & $200-500$ \\
\hline Leucocytes $\left(\mathrm{x} 10^{3} / \mu \mathrm{L}\right)$ & 7.7 & 8.2 & 6-17 \\
\hline Neutrophil & 6.16 & 6.64 & $3-11.5$ \\
\hline Eosinophil & 0.07 & 0 & $0.1-1.25$ \\
\hline Monocytes & 0.54 & 0.57 & $0.15-1.35$ \\
\hline Lymphocytes & 0.92 & 0.98 & $1-4.8$ \\
\hline Total Protein $(\mathrm{g} / \mathrm{L})$ & 8.2 & 9.2 & $6-8$ \\
\hline Albumin $(\mathrm{g} / \mathrm{L})$ & 3.4 & 2.9 & $2.6-3.3$ \\
\hline $\operatorname{ALT}(\mathrm{U} / \mathrm{L})$ & 168 & 347 & $<102$ \\
\hline $\operatorname{ALP}(\mathrm{U} / \mathrm{L})$ & 381 & 952 & $<156$ \\
\hline Cholesterol (mg/dL) & 330 & - & $135-270$ \\
\hline Creatinin $(\mathrm{mg} / \mathrm{dL})$ & 0.4 & 0.6 & $0.5-1.5$ \\
\hline Glucose (mg/dL) & 60 & 94 & $60-118$ \\
\hline Phosphorus (mg/dL) & 6.2 & - & $2.6-6.2$ \\
\hline Triglycerides (mg/dL) & 284 & - & $32-138$ \\
\hline Urea $(\mathrm{mg} / \mathrm{dL})$ & 27 & 33 & $20-60$ \\
\hline USG & 1,036 & - & $>1,030$ \\
\hline UP:CR & 0.04 & - & $<0.2$ \\
\hline Left Adrenal Gland & $\begin{array}{c}\text { Adrenomegaly and } \\
\text { hyperechogenicity with } \\
\text { caudal pole severe } \\
\text { thickening, } 4.13 \times 1.04 \times \\
2.92 \mathrm{~cm}\end{array}$ & $\begin{array}{l}\text { Adrenomegaly with oval and } \\
\text { heterogeneous appearance with } \\
2.55 \mathrm{~cm} \text { caudal pole thickness }\end{array}$ & $\begin{array}{c}\text { Maximum thickness } 0.74 \\
\mathrm{~cm}\end{array}$ \\
\hline Right Adrenal Gland & $\begin{array}{l}\text { Adrenomegaly } 1.95 \times 0.8 \times \\
0.47 \mathrm{~cm} \text { with a nodular } \\
\text { hyperechoic area at cranial } \\
\text { pole } 0.96 \times 0.61 \mathrm{~cm}\end{array}$ & $\begin{array}{l}\text { Adrenomegaly with oval and } \\
\text { heterogeneous appearance with } 1.4 \\
\text { cm caudal pole thickness }\end{array}$ & $\begin{array}{c}\text { Maximum thickness } 0.74 \\
\mathrm{~cm}\end{array}$ \\
\hline Basal cortisol & $2.72 \mu \mathrm{g} / \mathrm{dL}$ & - & $0.5-6 \mu \mathrm{g} / \mathrm{dL}$ \\
\hline Post-4h cortisol & $3.52 \mu \mathrm{g} / \mathrm{dL}$ & - & $<1 \mu \mathrm{g} / \mathrm{dL}$ \\
\hline Post-8h cortisol & $3 \mu \mathrm{g} / \mathrm{dL}$ & - & $<1 \mu \mathrm{g} / \mathrm{dL}$ \\
\hline
\end{tabular}

${ }^{*} \mathrm{ALT}=$ alanine aminotransferase, $\mathrm{ALP}=$ alkaline phosphatase, USG $=$ urinary specific gravity, UP:CR $=$ urinary protein to creatinine ratio.

fibrin, red blood cells, and leukocytes. The skeletal musculature contained multifocal areas of mild fiber necrosis associated with mild inflammatory infiltrate of lymphocytes, plasma cells, and macrophages. In the liver, several hepatocytes were enlarged and had a poorly defined pale eosinophilic cytoplasm with microvacuolation and central nucleus, compatible with glycogen accumulation. Marked cytoplasmic macrovacuolation of hepatocytes was also noted in a small number of hepatocytes, often displacing the nucleus to the periphery (fat accumulation). No histological changes were observed in the pituitary gland.
In the present case, the diagnosis of aortic and iliac thrombosis due to adrenal-dependent-HC was based on clinical and pathological findings. Distal aortic thrombosis associated with a bilateral adrenocortical adenoma is an uncommon condition in dogs (BEHREND et al., 2013; PACE et al., 2013). Dogs with hypercortisolism may have several comorbidities because long-term hypercortisolism causes multiple organ dysfunction (NICHOLS, 1997). Although infrequent, aortic thrombosis has been recognized as a secondary complication in dogs with HAC (BOSWOOD et al., 2000; LAKE-BAKAAR et

Ciência Rural, v.50, n.12, 2020. 


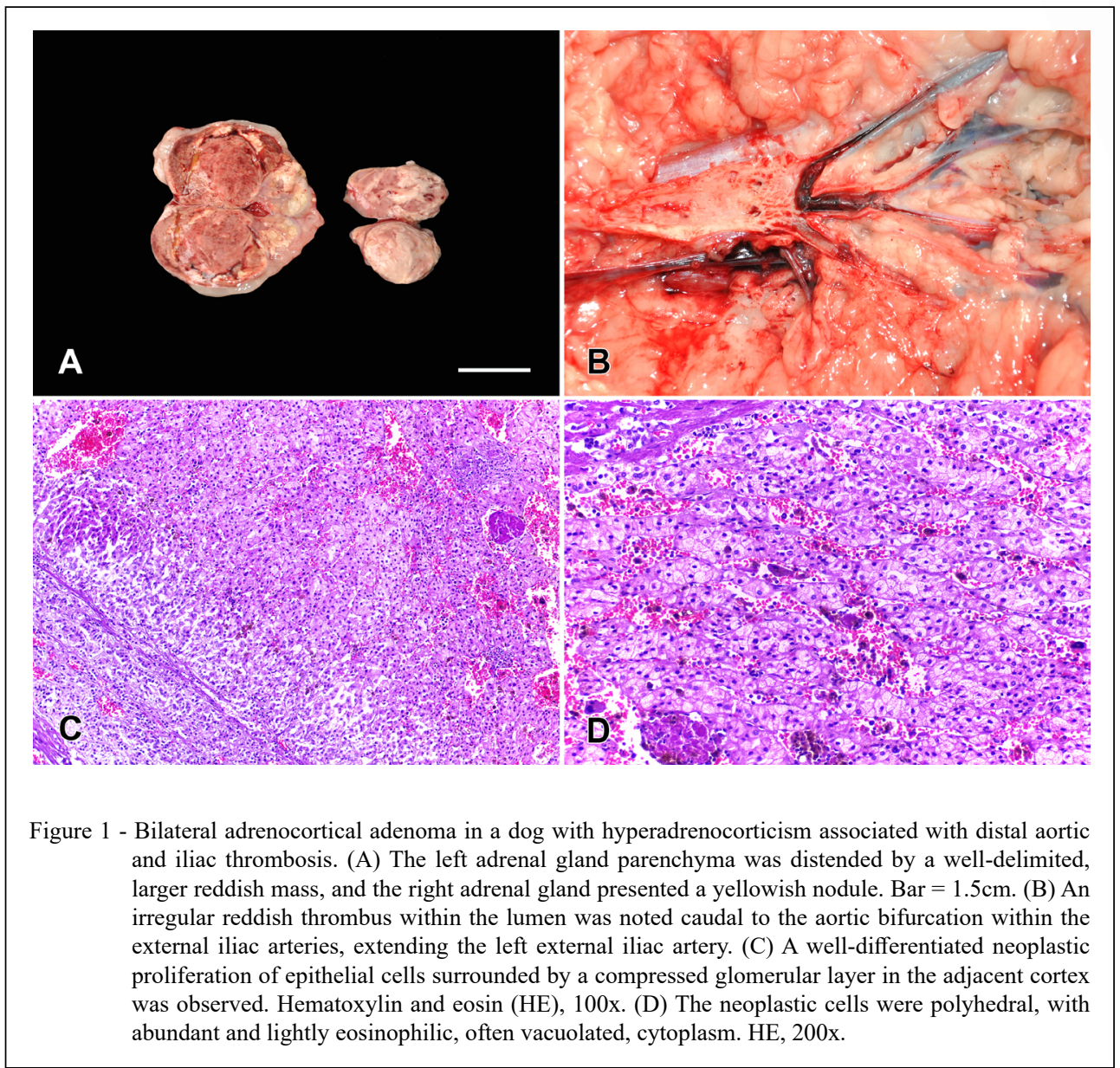

al., 2012; WINTER et al., 2012). The reported frequency ranges from $0 \%$ to $5.5 \%$ in relation to other diseases associated with canine aortic thromboembolism or aortic thrombosis (WILLIAMS et al., 2017).

While aortic thrombosis and aortic thromboembolism have often been used as synonyms in dogs, distinguishing between the two terms is currently considered to be more appropriate in veterinary medicine (WILLIAMS et al., 2017). In cats, thromboembolism is a well-defined condition, often involving thrombus formation within the left atrium, secondary to heart disease and, with acute embolization (SMITH \& TOBIAS, 2004). Nevertheless, previous studies have reported that aortic thrombosis in dogs is mainly caused by primary thrombus formation at the distal aorta, similarly to in the present study (BOSWOOD et al., 2000; WINTER et al., 2012). Thus, primary thrombosis, rather than thromboembolism, should considered first when aortic thrombi are documented in dogs (LAKE-BAKAAR et al., 2012).
Thrombosis in dogs with hypercortisolism is mainly correlated with a hypercoagulable state associated with factors expected to occur in $\mathrm{HC}$ such as thrombocytosis (NICHOLS, 1997). A previous study reported a mild increase in platelet count $(500-600.000 / \mu \mathrm{L})$ in more than $50 \%$ of dogs with thrombocytosis caused by endocrine diseases, similarly to the observations in the present case (WOOLCOCK et al., 2017). Other causes of thrombosis in dogs with Cushing's syndrome include decreased antithrombin concentrations secondary to glomerular changes and proteinuria, and decreased fibrinolysis (JACOBY et al., 2001). Relative increases in the concentrations of circulating procoagulant molecules, such as factor VIII and fibrinogen (DAL BO et al., 1983; JACOBY et al., 2001), have also been suggested as a cause.

When thromboembolic events occur in dogs with hypercortisolism, pulmonary vessels are primarily involved in acute respiratory distress 
(NICHOLS, 1997; BEHREND et al., 2013). In contrast, in the present case a single thrombus was observed only in the aorta and iliac extern arteries. A distal portion of the aorta appears to be the most common site of primary thrombi in dogs (LAKE-BAKAAR et al., 2012). In humans, patients with abnormally small or large aortic diameters cranial to the aortic bifurcation have an increased incidence of peripheral thrombosis. Aortic thrombosis is also associated with aneurysmal or atherosclerotic aortic regions (VAN DEN BOSCH et al., 2001; CRAWFORD et al., 2014).

In addition to $\mathrm{HC}$, protein-losing nephropathy, protein-losing enteropathy, infective endocarditis, and malignant neoplasia have also been recognized as causes of aortic thrombosis in dogs, and they must be differentiated (WILLIAMS et al., 2017; WINTER \& BUDKE, 2017; RIPPLINGER et al., 2020). In the present case, these causes were excluded.

Clinical signs of acute aortic thrombosis usually include hindlimb paresis or paralysis, absent or reduced femoral pulses, and cold extremities (BOSWOOD et al., 2000; GONÇALVES et al., 2008; LAKE-BAKAAR et al., 2012), similar to those observed in the present case. Hindlimb pain or nonspecific signs of discomfort, such as restlessness, panting, and vocalization, may also be noted (WILLIAMS et al., 2017). Acute paresis or paralysis of the hind limbs associated with pain is frequently associated with intervertebral disk degeneration (IVDD) in Dachshunds and others chondrodystrophic breed. Therefore, IVDD should be considered as an important differential clinical diagnosis for aortic thrombosis in these breeds (JEFFERY et al., 2013). In this case, thoracolumbar vertebral radiography was sufficiently able to rule out an IVDD diagnosis. Moreover, the observed femoral pulse weakness supported the thrombi hypothesis.

Primary cortisol-secreting adrenocortical tumors are the less frequent cause of naturally occurring Cushing's syndrome in dogs $(15-20 \%$ of cases), and the bilateral presentation in this case, is very uncommon (PETERSON, 2007). Adrenocortical adenomas occur more frequently than carcinomas, and are usually a single, partially or completely encapsulated well-demarcated nodule (ROSOL \& MEUTEN, 2016). As seen in the present study, larger cortical adenomas are yellow to red and may distort the external contour of the affected gland (ROSOL $\&$ GRONE, 2016). These findings are important in differentiating between bilateral adenomas and nodular cortical hyperplasia commonly seen in older dogs, as nodular cortical hyperplasia usually consists of multifocal nodules of different sizes in both adrenals, often outside the capsule, with no encapsulation (ROSOL \& GRONE, 2016).

Bilateral larger adenomas also must be differentiated from adrenocortical carcinomas, which can also present yellow to red nodules. In addition, both can be very similar histologically. However, carcinomas are larger than adenomas, and the definitive criteria of malignancy are local invasion through the adrenal capsule into surrounding tissues, vascular invasion, and metastasis (ROSOL \& MEUTEN, 2016). In the present case, the absence of local invasion and metastasis allowed bilateral adrenocortical adenoma to be confirmed. Moreover, the absence of hypophyseal abnormalities upon postmortem examination, as well as the hormonal profile during the LDDST, ruled out ACTH-dependent HC as a cause of bilateral adrenal tumor (BEHREND et al., 2013) and thrombosis (BOSWOOD et al., 2000).

Although very rare, bilateral functional adrenocortical adenoma should be considered as a cause of hypercortisolism in dogs, especially in cases where an abdominal ultrasound reveals heterogeneous bilateral adrenal enlargement and no suppression is detected in an LDDST. In addition; although uncommon, primary aortic thrombosis in dogs should be considered an important consequence of hypercortisolism and should be considered a differential diagnosis of canine hindlimb paresis.

\section{ACKNOWLEDGEMENTS}

This work was supported by Conselho Nacional de Desenvolvimento Científico e Tecnológico (CNPq), and it was financed in part by the Coordenação de Aperfeiçoamento Pessoal de Nível Superior (CAPES). Brasil - Finance code 001.

\section{BIOETHICS AND BIOSECURITY COMMITTEE APPROVAL}

We authors of the article entitled "Aortic and iliac thrombosis in a dog with adrenal-dependent hypercortisolism due to bilateral adrenocortical adenoma" declared, for all due purposes, the project that gave rise to the present data of the same has not been submitted for evaluation of the Ethics Committee of the Universidade Federal do Rio Grande do Sul (UFRGS), but we are aware of the content of the Brazilian resolutions of the Conselho Nacional de Controle de Experimentação Animal (CONCEA) if it involves animals. Thus, the authors assume full responsibility for the presented data and are available for possible questions, should they be required by the competent authorities.

\section{DECLARATION OF CONFLICT OF INTERESTS}

The authors declare no conflict of interest. The founding sponsors had no role in the design of the study; in the 
collection, analyses, or interpretation of data; in the writing of the manuscript, and in the decision to publish the results.

\section{AUTHOR CONTRIBUTIONS}

All authors contributed equally for the conception and writing of the manuscript. All authors critically revised the manuscript and approved the final version.

\section{REFERENCES}

BEHREND, E. N. et al. Diagnosis of spontaneous canine hyperadrenocorticism: 2012 ACVIM consensus statement (small animal). Journal of Veterinary Internal Medicine, v.27, n.6, p.1292-1304, 2013. Available from: <https://onlinelibrary.wiley. com/doi/full/10.1111/jvim.12192>. Accessed: Mar. 20, 2020. doi: 10.1111/jvim. 12192 .

BOSWOOD, A. et al. Aortic and iliac thrombosis in six dogs. Journal of Small Animal Practice, v.41, n.3, p.109-114, 2000. Available from: <https://onlinelibrary.wiley.com/doi/ abs/10.1111/j.1748-5827.2000.tb03176.x>. Accessed: Mar. 20, 2020. doi: 10.1111/j.1748-5827.2000.tb03176.x.

CRAWFORD, D. et al. A modern series of acute aortic occlusion. Journal of Vascular Surgery, v.59, n.4, p.1044-1050, 2014. Available from: <https://www.jvascsurg.org/article/S07415214(13)01988-5/fulltext>. Accessed: Mar. 20, 2020. doi: $10.1016 /$ j.jvs.2013.10.080.

DAL BO, Z. R. et al. Clotting changes in Cushing's syndrome: elevated factor VIII activity. Folia Haematologica (Leipzig, Germany: 1928), v.110, n.2, p.268-277, 1983. Available from: <https://europepmc.org/article/med/6194060>. Accessed: Mar. 20, 2020.

GONÇALVES, R. et al. Clinical and neurological characteristics of aortic thromboembolism in dogs. Journal of Small Animal Practice, v.49, n.4, p.178-184, 2008. Available from: <https:// onlinelibrary.wiley.com/doi/full/10.1111/j.1748-5827.2007.00530. $\mathrm{x}>$. Accessed: Mar. 20, 2020. doi: 10.1111/j.17485827.2007.00530.x.

JACOBY, R. C. et al. Biochemical basis for the hypercoagulable state seen in Cushing syndrome. Archives of Surgery, v.136, n.9, p.1003-1007, 2001. Available from: <https:/jamanetwork.com/ journals/jamasurgery/fullarticle/392130>. Accessed: Mar. 20, 2020. doi: 10.1001/archsurg.136.9.1003.

JEFFERY, N. D. et al. Intervertebral disk degeneration in dogs: consequences, diagnosis, treatment, and future directions. Journal of Veterinary Internal Medicine, v.27, n.6, p.1318-1333, 2013. Available from: <https://onlinelibrary.wiley.com/doi/full/10.1111/ jvim.12183>. Accessed: Mar. 20, 2020. doi: 10.1111/jvim.12183.

LAFLAMME, D. P. Development and validation of a body condition score system for dogs: a clinical tool. Canine Practice, v.22, n.3, p.10-15, 1997. Available from: <http:// agris.fao.org/agris-search/search.do?recordID=US9742264 $>$. Accessed: Apr. 14, 2020.

LAKE-BAKAAR, G. A. et al. Aortic thrombosis in dogs: 31 cases (2000-2010). Journal of the American Veterinary Medical Association, v.241, n.7, p.910-915, 2012. Available from: $<$ https://avmajournals.avma.org/doi/abs/10.2460/javma.241.7.91
0?journalCode=javma $>$. Accessed: Mar. 20, 2020. doi: 10.2460/ javma.241.7.910.

MELLO, F. P. S. et al. Sedation Effect of Acepromazine and Butorphanol in Dopplervelocimetric Parameters in Great Abdominal Arteries and Femoral Artery in Dogs. Acta Scientiae Veterinariae, v.44, p.1-7, 2016. Available from: $<$ https://www.seer. ufrgs.br/ActaScientiaeVeterinariae/article/view/81172/47613>. Accessed: Apr. 15, 2020.

NICHOLS, R. Complications and concurrent disease associated with canine hyperadrenocorticism. Veterinary Clinics: Small Animal Practice, v.27, n.2, p.309-320, 1997. Available from: <https://www.sciencedirect.com/science/article/abs/pii/ S0195561697500349?via\%3Dihub>. Accessed: Mar. 20, 2020. doi: 10.1016/S0195-5616(97)50034-9.

PACE, S. L. et al. Assessment of coagulation and potential biochemical markers for hypercoagulability in canine hyperadrenocorticism. Journal of Veterinary Internal Medicine, v.27, n.5, p.1113-1120, 2013. Available from: <https:// onlinelibrary.wiley.com/doi/full/10.1111/jvim.12159>. Accessed: Mar. 20, 2020. doi: 10.1111/jvim. 12159.

PETERSON, M. E. Diagnosis of hyperadrenocorticism in dogs. Clinical Techniques in Small Animal Practice, v.22, n.1, p.2-11, 2007. Available from: <https://www.sciencedirect.com/science/ article/abs/pii/S1096286707000084>. Accessed: Mar. 20, 2020. doi: 10.1053/j.ctsap.2007.02.007.

RIPPLINGER, A. et al. Aortic thrombosis in a dog with chronic lymphocytic leukemia. Ciência Rural, v.50, n.4, p.1-6, 2020. Available from: <http://www.scielo.br/pdf/cr/v50n4/1678-4596-cr50-04-e20190719>. Accessed: Apr. 11, 2020. doi: 10.1590/0103$8478 \mathrm{cr} 20190719$.

ROSOL, T. J.; GRÖNE, A. Endocrine Glands. In: MAXIE, M.G. (Ed.) Jubb, Kennedy and Palmer's Pathology of Domestic Animals. 6. ed. Ontario: Elsevier, 2016, v.3. Cap.3, p.269-357.

ROSOL, T. J.; MEUTEN, D. J. Tumors of the Endocrine Glands. In: MEUTEN, D. J. (Ed.) Tumors in Domestic Animals. 5. ed. Ames, Iowa: Wiley Blackwell, 2016. Cap.18, p.766-833.

SANDERS, K. et al. Treating canine Cushing's syndrome: Current options and future prospects. The Veterinary Journal, v.241, p.42-51, 2018. Available from: <https://www.sciencedirect.com/ science/article/pii/S1090023318306002?via\%3Dihub>. Accessed: Mar. 20, 2020. doi: 10.1016/j.tvj1.2018.09.014.

SMITH, S. A.; TOBIAS, A. H. Feline arterial thromboembolism: an update. Veterinary Clinics: Small Animal Practice, v.34, n.5, p.1245-1271, 2004. Available from: <https://doi.org/10.1016/j. cvsm.2004.05.006>. Accessed: Mar. 20, 2020. doi: 10.1016/j. cvsm.2004.05.006.

VAN DEN BOSCH, M. A. A. J. et al. Distal aortic diameter and peripheral arterial occlusive disease. Journal of Vascular Surgery, v.34, n.6, p.1085-1089, 2001. Available from: $<$ https:// www.jvascsurg.org/article/S0741-5214(01)44036-5/fulltext>. Accessed: Mar. 20, 2020. doi: 10.1067/mva.2001.118809.

WINTER, R. L. et al. Aortic thrombosis in dogs: presentation, therapy, and outcome in 26 cases. Journal of Veterinary Cardiology, v.14, n.2, p.333-342, 2012. Available from: $<$ https://www.sciencedirect.com/science/article/abs/pii/ 
S1760273412000549?via\%3Dihub>. Accessed: Mar. 20, 2020. doi: $10.1016 /$ j.jvc.2012.02.008.

WINTER, R. L.; BUDKE, C. M. Multicenter evaluation of signalment and comorbid conditions associated with aortic thrombotic disease in dogs. Journal of the American Veterinary Medical Association, v.251, n.4, p.438-442, 2017. Available from: <https:// avmajournals.avma.org/doi/abs/10.2460/javma.251.4.438?rfr dat $=$ cr_pub\%3 Dpubmed\&url_ver $=$ Z3 39.88-2003\&rfr $\mathrm{id}=$ ori $\% 3$ Arid $\% 3$ Acrossref.org\&journalCode $=$ javma $>$. Accessed: Mar. 20, 2020. doi: 10.2460/javma.251.4.438.
WILliamS, T. P. E. et al. Aortic thrombosis in dogs. Journal of Veterinary Emergency and Critical Care, v.27, n.1, p.922, 2017. Available from: <https://onlinelibrary.wiley.com/doi/ abs/10.1111/vec.12527>. Accessed: Mar. 20, 2020. doi: 10.1111/ vec. 12527 .

WOOLCOCK, A. D. et al. Thrombocytosis in 715 Dogs (20112015). Journal of Veterinary Internal Medicine, v.31, n.6, p.1691-1699, 2017. Available from: <https://onlinelibrary.wiley. com/doi/full/10.1111/jvim.14831>. Accessed: Mar. 20, 2020. doi: $10.1111 /$ jvim. 14831 . 